\title{
THE HOLSTEIN CATTLE BREEDING PARTICULARITIES IN RUSSIAN SMALL AND MEDIUM ENTERPRISES' CONDITIONS
}

\author{
Victoria Sidorova \\ Biotechnology Department Leading Research Worker \\ All-Russian Research Institute of Animal Husbandry Mechanization (VNIIMJ) \\ 31 Znamya Oktyabrya str., settlement Ryazanovsky, Moscow, 142134 \\ gdi20071@yandex.ru
}

\begin{abstract}
IT- information technologies play a crucial role in the animals breeding value of different breeding, production, morphological, physiological and other livestock groups determining on operation farms. All of these groups are genetic (30 \% - in countries with highly developed dairy cattle breeding, 5-25\% in herds of Russia) and technological reserves of milk production. Particularly its exploitation allows to create financial flows that determine the milk production success and farm's future prospects. The main objective of selection is economics, so livestock owner supports those milk production areas on his farm that give optimum profits. There are at the milk production a lot of such areas: feeding, keeping, excess or lack of staff, etc., Our research, based on experimental data $(n=25000)$ and the literature review had showed that the main of them is the genotype of the animal, so as the low-productive cattle overfeeding doesn't contribute more additional milk to obtain. The genotype influence is determined by technological, social, financial and other factors that allows to create a harmonious system of their interrelation $(r=0,01-0,9)$. Our researches had allowed to find a model that combines seemingly incompatible factors, and in the individual breeding programs form for the qualitative and quantitative genetics successful application regularities with the dominance of the latter, on small and medium-sized milk production enterprises it to apply.
\end{abstract}

Keywords: population genetics, body traits, animal model, correlated variability, information technologies.

\section{Introduction}

Modern methods of population genetics needs with great precision to identify effective ways of animals improving on the basis of individual and group assessment of their breeding qualities that makes the selection, according to N. I. Vavilov, words "the field of knowledge, directed by the will of man."

In Russia the first time computing technique - ES of the various generations for dairy cattle breeding working was applied by the research institute of farm animals breeding and genetics from 1961 till 64 years, it based on the dairy animals unique cards using methodology adapted to the breeding records bases machining. N. Z. Basovskay, S. P. Degtyareva reported in this connection that the VNIIRGJ computers technique in milk stock breeding methodology of since then was improved, and had found its expression in the form of science-based AIS "Insel", "SELEX", "Elite" information systems [1-3].

"SELEX" integrate automated system was developed in the early 70 -ies by the Latvian analytical station for animal breeding (L. K. Ernst, A. A. Zilitis, etc.). Based its milk yield information on the cattle production and reproductive ability within farm, area, region and republic the monthly reports were prepared. Outcome indicators were used for reporting on the bulls and cows bonitation, animal breeding value evaluation, based on the technology of punched cards.

"Elite" information-and-computational system was used mainly in Lithuania, as a dairy cattle initial automation accounting's centralized system. "Elite" information-computational system was developed by the Lithuanian Institute of agriculture economy. The program solved the following set of tasks: cattle milk production accounting and operational data analysis control, the cows' milking machine suitability, reproductive ability assessment, the young animals growth and development analysis. The database system creating and implementing was used "the Network" system plus 4 dialog system, "Computer - selector" with the (PPP) "Telespravka" and "Kama" applied programs packages. 
Automated information systems have solved the problems of large-scale selection focused mainly on the selection of bulls and the prediction of their breeding values within breed. Software systems SAS and LSML 76 were determined and evaluated selection and genetic parameters: variability, heritability, correlation, frequency, regression and etc., according to the investigated animal samples. It also includes assessment of the forecast of results of selection, interaction genotype environment, mistaking genetic differences, etc.

Automated information systems had solved the large-scale selection problems focused mainly on the bulls selection and their breeding values within breed prediction. SAS and LSML-76 software systems determined and evaluated selection - and- genetic parameters: variability, heritability, correlation, frequency, regression and etc., according to the samples of investigated animal. It also included the selection trend assessment, genotype - environment interaction, across-herds genetic differences, etc results estimate.

$\mathrm{K}$. Röningen determined the genetic progress variability indicators of the milk and butterfat yield breeding animals main categories of dairy cattle populations at the individual and mass selection using the Monte Carlo method (the method of least squares). The obtained results can be easily compared with the predicted genetic value's trend over different periods of time, depending on intensity of selection and the coefficients of heritability's magnitudes.

Currently, for biological objects processes mathematical modeling is used an application program Excel designed on a Windows environment working. In this regard, O. Koch, in «MS Excel ... for users" publishing reported that the module "Scenario Manager" allows to create a simulated relevant situations the given numerical values and its replacing using [4-6].

By VNIIRGJ scientists were optimized Simmental cattle large-scale breeding program in the breed and populations context. By the Fortran-IV algorithmic language for computer using there was modulated the breeding best options situation finding taking into account productive and economic factors.

Breeding programs and its numerous variants analysis require a lot of computer time. Therefore it is necessary to have an idea what variable factors are appropriate to include in the model and choose the best from all the options.

A effective selection's mandatory condition is animal feeding and maintenance level consideration. Using these factors were created genetic-and-mathematical models, statistically the most reliably determining its impact on the breeding traits variability. In this regard, C. R. Henderson, R. L. Quaas, reported that the most effective dairy cattle BLUP model determined phenotypic manifestation of ijklm-th heifers productivity with $\mu$ - average population's productivity, $\mathrm{Hi}$ - was the i- herd level effect (eijklm farms is the of unaccounted factors effect). The model is characterized by high determination coefficients (suitability) and the calculated coefficients statistical significance.

It is known that the smaller variances amount accounted the residual one, the more accurate the estimated variability factors. Therefore, in the mathematical-and-statistical model it should be included the largest possible number of factors: housing technology, health status, type of feeding, milking frequency, etc. American Association of Holstein cattle on the "Sire Summaries" directory analyzed materials basis over several decades reported that the breed milk yield level variability main factors were the animals' feeding and housing systems level, which accounted for $35 \%$. The animal genotype included - $25 \%$, health condition - $25 \%$, year and season of calving - $15 \%$. H. Skjervold believed that about $20 \%$ of the variance depends on the milking multiplicity. If variability affecting factors are numerous, the model reflected the different combinations of them and the most common intermediate states more fully [7-10].

Currently, the herd management processes modeling issues are in the further development process. In the atomization-and- information systems, they will solve the problems of breeding work planning, of breeding results evaluating, the production economic efficiency and many others. Literature available contradictory data and the small groups fundamental research lack, indicate the under discussion issue relevance and great practical significance [11, 12]. 


\section{The aim}

Was the successful milk production enterprise parameters on Russian small or medium-sized farms base determining.

\section{Material and research methods}

Studies conducted on number of Holstein black-and-white breed's cows more than 24 thousand heads. In Russia, the experimental data were obtained in herds of after Dzerzhinsky farm, "Krasnaya Niva" GPZ, "State farm "Arkhangelsky" OOO, and other farms of the Moscow region. In the CIS farms the scientific-and-production experiments were conducted on the Kant's machine station's experimental cooperative (OPH MIS) herd farms. The cows of purebred USA Holstein breed, the world best one in the milk production level, were included for studying of its patterns its high milk yield determining and the possibility of these patterns on the under controlling farms using. As material of study also were the lists of top 100 USA bulls, United States and Russia bulls directory. It also were reviewed the dairy farms initial zootechnical accounting's materials: breeding accounting cards, bonitation books, pedigree enterprises working quarterly reports, etc.

The farms' classification by dairy farming productivity type was conducted on the Russian Federation Ministry of agriculture recommendations' base. For studies were also used zootechnical and technological methodologies: “The young Holstein bulls - sons of the breeds' leaders using", "The ways and forms of creation and preservation of valuable gene pool of local breeds", dairy cows linear type evaluation, developed by Holstein Association USA specialists (Program Linear Type Evaluations, Holstein Association USA, 1977-1990, G. R. Wiggans, et all).

\section{The results of the study}

The dairy cattle breeding small farm production capacity operation efficiency is determined by both genetic and technological (environmental) factors. Our studies were based on highest genetic and economic value main factors allocating and its separation from not the main. For this the materials of research were divided into several information blocks, including similar genetic and technological characteristics' data. At the same time were reviewed the results the research of dairy cattle highly developed countries scientists.

Average herd's size in the Holstein cattle breeding traditional sites is 109 dairy cows. Therefore, the American model was taken as the study base on the cows milk yield of small herds level conditions determining (Fig. 1).

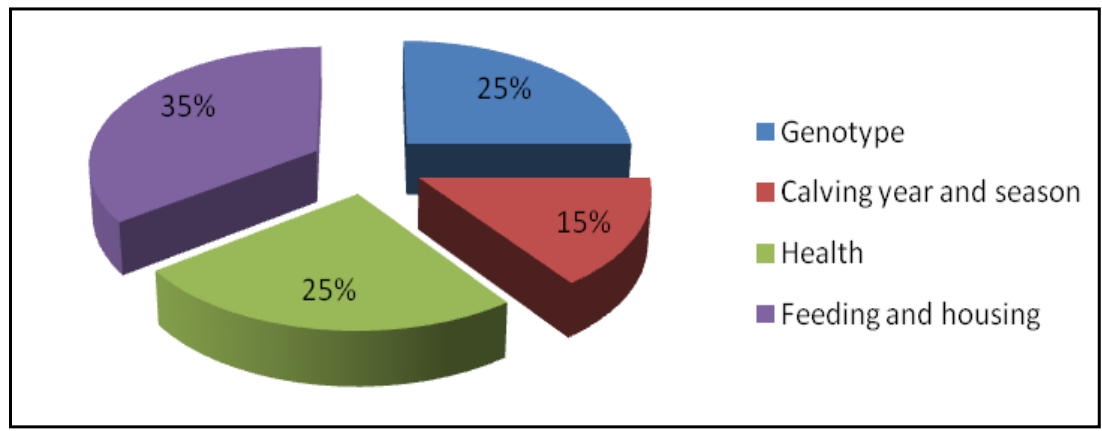

Fig. 1. The factors determining USA Holstein Association herds genetic diversity, \%

The research conducted on Russian and Kyrgyzstan small decentralized herds, in contrast to the large-scale selection methods of cattle breeding did not reveal any significant calving season impact on cow milk production of $(\mathrm{P}>0,01)$, and the calving year and season changes were determined largely by the sire breeding value and dairy population's genetic trend (Table 1).

In our research result had found a new factor of influence, which was absent in the American model of successful production, defining small enterprise efficient activity - the human factor. For example of "Krasnaya Niva" GPZ were studied the impact of subsistence productivity on the 
enterprise efficiency. Subsistence productivity here is allowed to increase salaries of engaged milk production employees in $11-13 \%$, and in $25 \%$ paid the animals feeding cost.

Table 1

OPH MIS cows ( $\mathrm{n}=33$ ) 305 days milk yield depending on the calving season, $\mathrm{kg}$

\begin{tabular}{|c|c|c|c|c|c|c|c|}
\hline \multicolumn{8}{|c|}{ Season of calving, $\mathrm{kg}$} \\
\hline \multicolumn{2}{|c|}{ Winter $(12,1,2)$} & \multicolumn{2}{|c|}{ Spring $(3,4,5)$} & \multicolumn{2}{|c|}{ Summer $(6,7,8)$} & \multicolumn{2}{|c|}{ Autumn $(9,10,11)$} \\
\hline $\mathrm{M} \pm \mathrm{m}$ & $\sigma$ & $\mathrm{M} \pm \mathrm{m}$ & $\sigma$ & $\mathrm{M} \pm \mathrm{m}$ & $\sigma$ & $\mathrm{M} \pm \mathrm{m}$ & $\sigma$ \\
\hline 5342 & - & $5216 \pm 391,3$ & 1173,8 & $5541 \pm 349,6$ & 1398,4 & $5445,1 \pm 524,7$ & 1390,9 \\
\hline
\end{tabular}

In general, genetic-and-technological model of small production Russian successful enterprises facilities engaged in the milk production, took the form of: $0,25 \mathrm{~g}+0,20 \mathrm{x}+0,15 \mathrm{y}+0,20 \mathrm{k}+0,20 \mathrm{w}=1$, where $\mathrm{g}$ is the genotype, $\mathrm{x}$ - feeding, $\mathrm{y}$ - housing, $\mathrm{k}$ - health, $\mathrm{w}$ - human factor (Fig. 2).

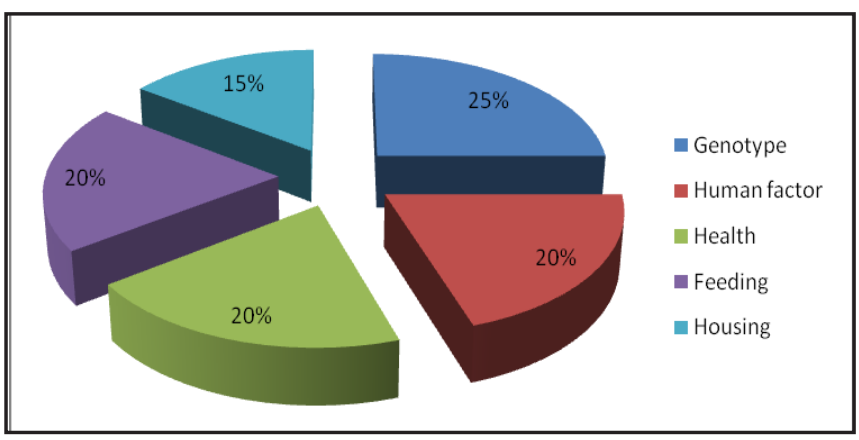

Fig. 2. The factors determining Russian small farms milk production, $\%$

All factors were equally important for small productivity enterprises. However, the various cattle owners had various specific problems; their features highlighted the second genetic-technological model's informative level of the milk production percentage-and- share impact - components of the main factors (Table 2).

\section{Table 2}

The small farms' components of the main factors of percentage-and- share impact on milk production

\begin{tabular}{ccccc}
\hline \multicolumn{4}{c}{ Main factors } \\
\hline Genotype & Feeding & Housing & Health & Human factor \\
\hline Bull breeding value & Own feeding base & Milking & Vet prevention & Milk yield increasing \\
Breed & Imported feed & Movement & Artificial insemination & Economical management \\
$\begin{array}{c}\text { Genetic poten-tial } \\
\text { realisation } \\
\text { Reproduction }\end{array}$ & Partly imported feed & Tie-free stall housing & Calving & Loans, inncen-tives, \\
Subsidies
\end{tabular}

Among the main factors' components are such as bull breeding value; the cross of lines, breed's inbreeding and heterosis, the genetic potential realization, reproduction, body characteristics, adapting, feeding, housing, health and care conditions.

The small farms effective activity main factors and its components in a single model identifying allows to meet more fully with the enterprise economy's problems and resources. The model shape is stable due to of the optimal number of main factors expense, so as it is finite due to the limited number of main factors, and it is volume due to the number of unlimited components. 


\section{The obtained results discussion}

The genetic potential realization was weakly depending on the herd productivity level, for example, so as both the lowest and the highest value of the milk yield genetic potential realization was observed in an average productivity milk level of domestics herds such as 5711-6620 kg per lactation.

In milk fat there was viewed the same situation, so as the most and least milk fat herds had a median value of indicators of this feature implementation. The milk and butterfat yield rank correlation coefficients respectively were equal to $r_{s}=0,3$ and 0,1 .

Modern methods of selection and genetic parameters calculation by PC programs using, including MS Excel-2000 had been allowing the cattle butterfat and milk yield value changing prediction to make. Among this program statistical functions such that are counting from a known curve values of their future ones, extrapolating (predicting) identified pattern.

Obtained in this way parameters had showed that the Russian Holstein breed's cows butterfat content by 2010 would reach 3,9\%, and their American contemporaries of 3,74 \%. The predict adequately consistent with the Head reproduction centre data on $1^{\text {st }}$ of May, 2010 - in this period, the average Holstein cattle butterfat in under controlled herds $(\mathrm{n}=1315)$ was 5170 and more $\mathrm{kg}$ of milk per the first lactation, with $3,92 \%$ fat content.

The study of quantitative characteristics genetics in accordance with the quantitative genetics ones enabled the creation of system the milk model animal obtaining, taking into account the main factors of genetic and technological model and its components - on the application of the quality genetics characteristics' dominance base, namely, the animal body traits using physic based on the ratio of the mutual influence of body different parameters. Thus, on their analysis base it was found that the selection for milk yield increasing can conduct in possible on any body traits, including such as height, body depth, heel height, the height of the udder rear, teats position, length of teats, etc., which in varying degrees are linked (Table 3).

Table 3

The Russian dairy cattle exterior traits relationship $(\mathrm{n}=1090)$

\begin{tabular}{|c|c|c|c|c|c|c|c|c|c|c|c|c|c|c|c|c|c|}
\hline Body traits & $\begin{array}{l}\text { Stat } \\
\text { ure }\end{array}$ & $\begin{array}{l}\text { Body } \\
\text { depth }\end{array}$ & $\begin{array}{l}\text { Rump } \\
\text { angle }\end{array}$ & $\begin{array}{l}\text { Rump } \\
\text { width }\end{array}$ & $\begin{array}{l}\text { Legs } \\
\text { (side) }\end{array}$ & $\begin{array}{c}\text { Foot } \\
\text { angle }\end{array}$ & $\begin{array}{c}\text { Legs } \\
\text { (rear) }\end{array}$ & $\begin{array}{c}\text { Fore } \\
\text { attach- } \\
\text { ment }\end{array}$ & $\begin{array}{c}\text { Rear } \\
\text { udder } \\
\text { height }\end{array}$ & $\begin{array}{c}\text { Udder } \\
\text { cleft }\end{array}$ & $\begin{array}{l}\text { Udder } \\
\text { depth }\end{array}$ & $\begin{array}{c}\text { Front } \\
\text { teat pla } \\
\text { cement }\end{array}$ & $\begin{array}{c}\text { Front } \\
\text { teat } \\
\text { length }\end{array}$ & Strength & $\begin{array}{l}\text { Dairy } \\
\text { form }\end{array}$ & $\begin{array}{l}\text { Feet } \\
\text { and } \\
\text { legs }\end{array}$ & $\begin{array}{c}\text { Rear } \\
\text { udder } \\
\text { width }\end{array}$ \\
\hline Stature & & - & - & - & - & - & - & - & - & - & - & - & - & - & - & - & - \\
\hline Body depth & 0,26 & - & - & - & - & - & - & - & - & - & - & - & - & - & - & - & - \\
\hline Rump angle & 0,75 & 0,18 & - & - & - & - & - & - & - & - & - & - & - & - & - & - & - \\
\hline Rump width & 0,78 & 0,40 & 0,96 & - & - & - & - & - & - & - & - & - & - & - & - & - & - \\
\hline Legs (side) & 0,65 & 0,23 & 0,71 & 0,68 & - & - & - & - & - & - & - & - & - & - & - & - & - \\
\hline Foot angle & 0,22 & $-0,04$ & 0,1 & 0,09 & 0,08 & - & - & - & - & - & - & - & - & - & - & - & - \\
\hline Legs (rear) & $-0,31$ & 0,12 & $-0,26$ & $-0,22$ & $-0,24$ & $-0,23$ & - & - & - & - & - & - & - & - & - & - & - \\
\hline $\begin{array}{l}\text { Fore attach- } \\
\text { ment }\end{array}$ & 0,18 & 0,14 & 0,26 & 0,24 & 0,33 & & & - & - & - & - & - & - & - & - & - & - \\
\hline $\begin{array}{c}\text { Rear udder } \\
\text { height }\end{array}$ & 0,45 & 0,13 & 0,33 & 0,31 & 0,38 & 0,0001 & $-0,54$ & 0,48 & - & - & - & - & - & - & - & - & - \\
\hline Udder cleft & 0,13 & 0,31 & 0,11 & 0,16 & 0,15 & & & & 0,50 & - & - & - & - & - & - & - & - \\
\hline Udder depth & 0,38 & 0,12 & 0,32 & 0,31 & 0,41 & & 0,01 & 0,0001 & 0,29 & 0,08 & - & - & - & - & - & - & - \\
\hline $\begin{array}{l}\text { Front } t \\
\text { placem }\end{array}$ & 0,37 & 0,31 & 0,36 & 0,38 & 0,44 & 0,01 & & 0,06 & 0,38 & 0,08 & 0,54 & - & - & - & - & - & - \\
\hline $\begin{array}{l}\text { Front teat } \\
\text { length }\end{array}$ & 0,42 & 0,43 & 0,59 & 0,59 & 0,56 & 0,08 & $-0,08$ & 0,17 & 0,37 & 0,16 & 0,52 & 0,83 & - & - & - & - & - \\
\hline Strength & 0,23 & 0,34 & 0,13 & 0,2 & 0,33 & 0,09 & 0,10 & 0,09 & 0,26 & 0,19 & 0,48 & 0,28 & 0,39 & - & - & - & - \\
\hline Dairy form & 0,47 & 0,15 & 0,12 & 0,10 & 0,26 & 0,07 & $-0,02$ & $-0,06$ & 0,32 & 0,02 & 0,73 & 0,28 & 0,11 & 0,45 & - & - & - \\
\hline $\begin{array}{l}\text { Feet and } \\
\text { legs }\end{array}$ & 0,03 & 0,21 & 0,08 & 0,11 & 0,13 & 0,17 & 0,15 & 0,02 & 0,02 & 0,05 & 0,41 & $-0,01$ & 0,25 & 0,64 & 0,26 & - & - \\
\hline $\begin{array}{l}\text { Rear udder } \\
\text { width }\end{array}$ & 0,26 & 0,08 & 0,21 & 0,24 & 0,29 & $-0,21$ & $-0,06$ & $-0,05$ & 0,15 & 0,05 & 0,02 & 0,13 & 0,06 & $-0,07$ & 0,02 & $-0,35$ & - \\
\hline
\end{tabular}




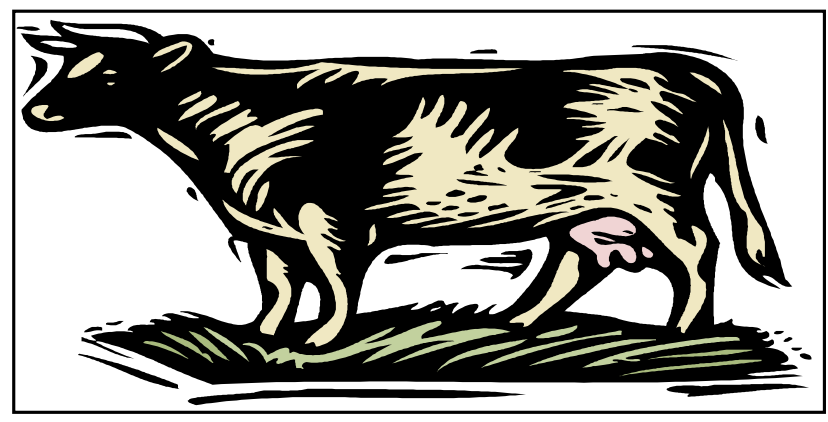

Fig. 3. Model of basic body form cow

There in herd was formed a reference group of cows possessing the desired traits - the group was the active part of the population (Fig. 4).

The selected group cows turned out to be well-developed body middle and back part, and more developed udder than had the rest of the cow groups.

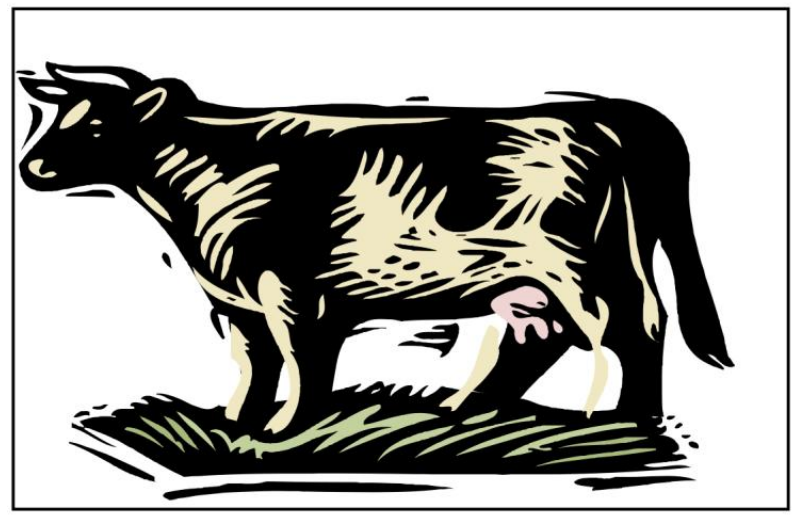

Fig. 4. Model of intermediate form cow of the active part of the population

Regular culling has allowed to get the cows model, with improved skeletal system, the udder and mammary system good properties (Fig. 5).

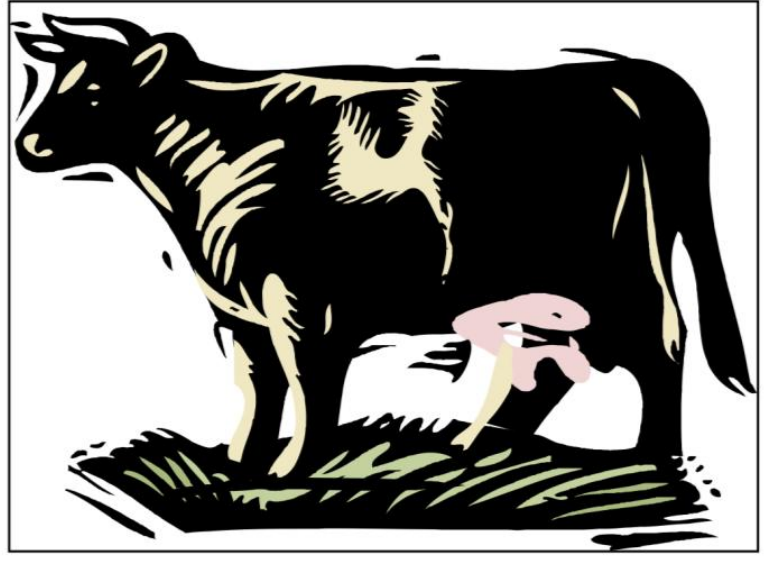

Fig. 5. Model milk form cows of the main herd

Sires used in the herd were checked of their body traits relationship evidence, and the their own body correlation values establishing, as well as their own body traits and productive qualities of offspring correlation's establishing. Life longevity increased by 0,4 lactation by the reproduction system improving. 


\section{Conclusions}

1. Optimization of the cattle breeding simultaneous genetic and technological factors using in the same model allows to identify the most effective options for their implementation and through small and medium-sized farms' plans and programs development inclusion.

2. USA breeding Holstein cow form to the greatest degree correlates with the rates of milk yield, and a Russia selection cow with the life longevity and fat content.

3. The rank correlation coefficients between the Holstein breed bulls exterior characteristics ratio and their Russian daughters productive qualities, made up of 0,9 of the milk yield and 0,4 of butterfat $\%$.

4.There was a significant relationship between the milk yield level and different cows body characteristics by a linear score, which reaches $r=+0,34+0,63$ value.

5. The of the coefficients of relative variability of different body parts using helps to identify their relationship with and quantitative genetics traits to establish individual breeding in a specific herd based on individual selection.

\section{Acknowledgement}

I thank a lot for the help in carrying out this study my scientific consultant doctor of biological sciences professor N. A. Popov, collaborators Dr. K. A. Weigel, M-r T. Halbach, managers S. Ueta, M. Okubo, and also staff of research institutions VIJ after L. K. Ernst, institute of biotechnology of National Academy of Sciences, Kyrgyz institute of animal husbandry and pasture, organizations section of bio projects of America, funds of Civil research and development foundation "U. S Civilian Research and Development Foundation", "ISTC", Soros Foundation-Kyrgyzstan", "Fulbreitscolarship", "IREX”.

\section{References}

[1] Baranov, V. A., Baranova, N. C., Glushchenko, M. A. (2005). Breeding and genetic evaluation of linear families in dairy farming. VIJ, 63 (1), 72-76.

[2] Weigel, K. A. (2002). Cow longevity: how traits enhance of reduce a cow's live. Hoard's Dairyman, 25, 244.

[3] Loginov, J. G., Rakhmatullina, N., Borgomastrova, O. (2006). Early assessment of the heifers on productive-and-exterior index. Dairy and beef cattle breeding, 6, 28-30.

[4] Popov, N. A., Eremina, N. A., Marasanova, L. K., Popov, A. N., Chervakov, N. A., Smirnova, G. G. (2005). Genetic features of Kholmogorska cattle breed of pedigree farms of Kirov region. Proc. scientific.of VIJ, 63 (1), 148-150.

[5] Prokhorenko, P., Mikhaylov, D. (2000). Influence of genetic and environmental factors on holsteinized cattle body form. Dairy and beef cattle breeding, 2, 23-25.

[6] Sidorova, V. Y., Popov, N. A. (2007). The probability of an effective choice of the list of USA top 100 bulls. Proceedings NAS KR, 1, 62-64.

[7] Strekozov, N. I., Levina, G. N. (2001). Individual selection based on the animals forms and breeding sires. Zootechnia, 1, 2-3.

[8] Andersen, G. R. (2002). Employee costs are more than salaries and benefits. Hoard's Dairyman, 25, 244.

[9] Ernst, L. K., Zinov'eva, N. A. (2004). Genetic basis of farm animals breeding. Moscow: RASHN, VIJ, 733.

[10] Arkhipov, A. V. et. al (2003). Technological bases of production and processing of animal products. Moscow: Izd-vo MGTU after N. E. Bauman, 804.

[11] Bakai, A. V., Kochish, I. I. (2000). Genetics and the biotechnology base. Moscow, 23.

[12] Kislyakov, A. V. (2000). Genetic algorithms: mathematical analysis of some schemes of reproduction. Information technology, 12, 9-14.

[13] Bolgov, A. E., Konovalov, M. P. (2008).Variation and inheritance of breeding value index of bulls of black-and-white Ayrshire in Finland. Zootechnia, 6, 4-6.

[14] Grigoryev, Y. N., Ilenkova, E. V., Osadchaya, O. A. (1997). The highly productive cows of black-motley breed getting. Zootechnia, 2, 2-3. 
[15] Wiggans, G. R. (1997). NCDHIP participation as of January 1, 1997. Fact Sheet K-1. Extension Servise, US Department of Agriculture. Washington DC, 32-35.

[16] Zhebrovsky, L. S. et. al (2005). The state of the gene pool of dairy cattle in Russia. Bulletin of the RASHN, 5, 78-79.

[17] Van Tassel, C. P. (1997). Changes in USDA-DHIA genetic evaluations (August 1997). AIPL. Res. Rpt., 9 (8-97).

[18] Hoffman, K. (2002). We must widen our genetic focus. Hoard's Dai-ryman, 25, 244.

[19] Kuznetsov, V. M. (2002). Holsteinisstion of Kholmogorsky cattle in the Kirov region. Zootechnia, 2, 8-10.

[20] Cassel, B. (2002). What longevity traits should you select? Hoard's Dairyman, 25, 244.

\section{POLYMORPHISMS OF DRUG-METABOLIZING ENZYMES CYP1A2, CYP2D6, GST, NAT2 AND TRANSPORTER MDR1 IN POPULATION OF BELARUS: COMPARISON WITH SELECTED EUROPEAN AND ASIAN POPULATIONS}

Alena Mikhalenka

Laboratory of cryopreservation of genetic resources Institute of Genetics and Cytology NASB michalenko75@mail.ru

\section{Natalia Chebotareva}

Laboratory of cryopreservation of genetic resources Institute of Genetics and Cytology NASB michalenko75@mail.ru

\section{Evelina Krupnova}

Laboratory of cryopreservation of genetic resources Institute of Genetics and Cytology NASB ekrupnova@inbox.ru

Anna Shchayuk

Laboratory of cryopreservation of genetic resources Institute of Genetics and Cytology NASB michalenko75@mail.ru

\section{Natalia Chakava}

Laboratory of cryopreservation of genetic resources Institute of Genetics and Cytology NASB

n.chakava@igc.by

\section{Svetlana Niyazava}

Laboratory of cryopreservation of genetic resources Institute of Genetics and Cytology NASB

n.chakava@igc.by

Abstract

Drug therapeutic efficiency and development of unfavorable pharmacologic responses as well as the disease predisposition are caused first of all by patient's genetic features. Genetic variations in genes encoding drug-metabolizing enzymes and transporter proteins are essential to understand the ethnic differences in disease occurrence, development, prognosis, therapeutic response and toxicity of drugs. For that reason, it is necessary to establish the normative frequency distribution of genotypes and alleles of these 